\title{
Pediatrik Hastalarda Postoperatif Dönemde Ağrı ve Deliryumu Ayırt Etmede FLACC ve OPS Ölçeklerinin Karşılaştırılması
}

\section{The Comparison of FLACC and OPS Scales in Differentiating Pain and Emergence Delirium in the Postoperative Period in Pediatric Patients}

\author{
${ }^{1}$ Kevser PEKER, ${ }^{2}$ Seydi Ali PEKER \\ ${ }^{1}$ Kırıkkale University School of Medicine, Department of Anesthesiology and Critical Care, Kırıkkale, Turkey \\ ${ }^{2}$ Kırıkkale Yüksek Ihtisas Hospital, Department of Biochemistry, Kırıkkale, Turkey
}

Kevser Peker: https://orcid.org/0000-0003-4306-5536

Seydi Ali Peker: https://orcid.org/0000-0002-2585-3267

\section{ÖZ}

Amaç: Postoperatif ağrı ve pediyatrik deliryum (ED) postoperatif erken dönem negatif davranışlarıdır. Ancak birbirinden ayırt etmek çok zordur. Bu çalışmanın amacı, postoperatif erken dönemde ağrıyı ve ED'yi ayırmada FLACC ve OPS ölçeğinin kullanılabilirliğini karşılaştırmaktır.

Materyal ve Metot: Bu prospektif çalışma bir üniversite hastanesinde yürütülmüştür. Altmış bir (61) çocuk çalıșmaya dâhil edilmiştir. Tüm çocuklara genel anestezi uygulanmıştır. ED insidansı PAED skalası ile ağrı insidans postoperatif dönemde hem FLACC hem de OPS skalaları ile değerlendirilmiştir.

Bulgular: En az bir değerlendirme zamanında, sadece deliryumlu çocuk sayısı $29(\% 47,5)$, ağrisı olan çocuk sayıs1 $10(\% 16,4)$ ve hem deliryum hem de ağrısı olan çocuk sayısı $25(\% 40,9)$ idi. FLACC için 5. dakikada eğrinin altındaki alan $(\mathrm{AUC}=0.914, \mathrm{P}=0.02)$ ve 15 . dakikada eğrinin altındaki alan $(\mathrm{AUC}=0.865, \mathrm{P}<0.001)$ yüksekti.

Sonuç: FLACC' in pediyatrik hastalarda postoperatif dönemde ağrı ve deliryumu ayırt etmede kullanılabilirlği OPS'dan daha iyidir.

Anahtar Kelimeler: Ağrı, deliryum, FLACC ölçeği, OPS ölçeği, PAED ölçeği

\begin{abstract}
Objective: Postoperative pain and pediatric emergence delirium (ED) are early-postoperative negative behaviours. However it is very difficult to diferentiate each other. The aim of the present study is to compare the utility of "Face, legs, Activity, Cry, Consolability" (FLACC) and Objective Pain Scale (OPS) in differentiating the pain and ED in the early postoperative period.
\end{abstract}

Materials and Methods: This prospective study was conducted at a university hospital. Sixty one (61) children were included in this study. General anesthesia was provided for all children. The incidence of ED was evaluated with PAED scale, the incidence of pain was evaluated with both FLACC and OPS scales in the early postoperative period.

Results: Only the number of children with delirium were $29(47.5 \%)$, with pain were $10(16.4 \%)$ and with both delirium and pain were $25(40.9 \%)$. For FLACC, the area under the curve $(\mathrm{AUC}=0.914, \mathrm{p}=0.02)$ at the 5 th minute and the area under the curve value $(\mathrm{AUC}=0.865$, $\mathrm{p}<0.001)$ at the 15 th minute was high.

Conclusion: The utility of FLACC is better than OPS in differentiating pain and emergence delirium in the postoperative period in pediatric patients.

Keywords: Delirium, FLACC scale, OPS scale, PAED scale, pain,

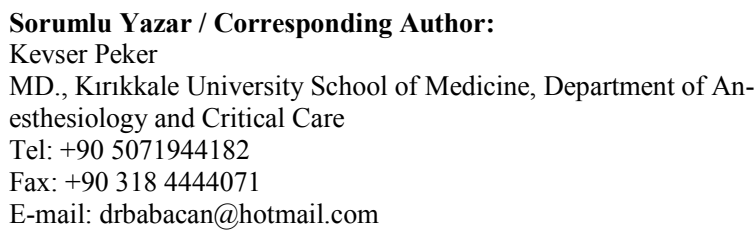

Yayın Bilgisi / Article Info:

Gönderi Tarihi/ Received: 05/09/2020

Kabul Tarihi/ Accepted: 11/09/2020

Online Yayın Tarihi/ Published: 30/12/2020

Atıf / Cited: Peker K and Peker SA. The comparison of FLACC and OPS scales in differentiating pain and emergence delirium in the postoperative period in pediatric patients. Online Türk Sağlık Bilimleri Dergisi 2020;5(4):602-611. doi: 10.26453/otjhs.777222 


\section{INTRODUCTION}

Emergence delirium is a comman complication characterized by symptoms such as crying, irritability, unconsciousness and disorientation observed in the early postoperative period in pediatric patients. ${ }^{1}$ The child in emergence delirium becomes harmful to himself and his environment, can pull his own catheter and cables and due to this situation, more personnel workforce is needed. ${ }^{2}$ The diagnosis of ED is according to clinical feature. Despite being clinically diagnosed, some scales (each of them have some advantages and disadvantages) such as the Pediatric Anesthesia Emergence Delirium (PAED) scale, Watcha scale and Cravero scale have been developed as descriptive. ${ }^{3}$ The PAED scale is the most commonly used scale first described by Sikich et $\mathrm{al}^{4}$ and is recognized as the standart tool.

Pain is a subjective common complaint in the children in the postoperative period. Postoperative recovery time and hospital stay was prolonged by pain if it was not diagnosed and treated. ${ }^{5}$ The difficulty of the pain manegement in children is to evaluate the intensity of pain. ${ }^{5}$ Many tools were developed for assessment of pain for improving the comfort of the children and the parents. ${ }^{5}$ The evaluation of pain is based on behavioural (irritability, restlessness, crying, sobbing, aggressiveness, loss of appetite, unusual posture, restlessness, disturbed sleep) and physiological indicators (skin colour/sweating, arterial blood pressure, heart rate, respiratory rate, posture, oxygen saturation) and age in children. ${ }^{6}$ "Face, legs, Activity, Cry, Consolability" (FLACC) scale is one of the comman easy assessment tool that measured the behavior of nonverbal or pre verbal child. ${ }^{7}$ Objective pain scale (OPS) is another scale for pain assessment which incorporates both behavioral indicator (crying, movement, agitation, verbalization) and physiological indicator (blood pressure change) in children. ${ }^{8}$

Both of the pain and pediatric emergence delirium are early-postoperative negative behaviours that have divergent trends over time. ${ }^{9}$ However is is very difficult to distinguish each other because at the same time pain-related behaviours can be evaluted as emergence delirium. ${ }^{9}$ If the distinction between the ED and pain was not made, this can lead to treatment of an often self-limiting adverse condition (ED) using an overdose of medication, or insufficient postoperative pain relief or delayed treatment. ${ }^{9}$

The aim of the present study is to compare the utility of FLACC and OPS scale in differentiating the pain and ED in the early postoperative period.

\section{MATERIALS AND METHODS}

The approval of this study was obtained from Institutional Ethics Committe (Date: 06.02.2020, decision no: 2020/09). This prospective observational study was conducted in the university hospital between February 2020 and June 2020 according to the Declaration of Helsinki. The written informed consent form was obtained from all parents of the participants.

American Society of Anesthesiologists (ASA) phsical status 1 and 2, aged between 3-8 years 61 patients who underwent adenoidectomy, adenotonsillectomy and ventilation tube placement were included in the study. Patients with growth and development retardation, neurological disease, psychiatric disease, cardiac disease, liver and kidney failure, epilepsy, used bronchodilator for asthma every day, allergy to drugs used, severe sleep apnea syndrome were excluded from the study.

Preoperative anxiety was measured by modified Yale preoperative anxiety scale (m-YPAS) in the patients ward 1 hour before the surgery. None of the patients received premedication for sedation. The parents were not present in the operating theatre. Standart monitorization ( non invasive blood pressure, peripheral oxygen saturation, heart rate and capnography) was made in the operating theatre. The induction of anesthesia was made via inhalation of sevoflurane $(8 \mathrm{vol} \%)$ in nitrous oxide $(60 \%)$ and oxygen $(40 \%)$ in a flow of 4 liters of fresh gas. The mask Acceptance Scale (MAS) was applied for all children at the time of mask induction. After the intravenous catheter was inserted, $5-7 \mathrm{mg} / \mathrm{kg}$ thiopental, $1-2 \mathrm{mcg} / \mathrm{kg}$ fentanyl were administered. Rocuronium $(0.6 \mathrm{mg} / \mathrm{kg})$ was given to facilitate intubation. Sevoflurane $(2 \%)$ in $50 \% \mathrm{~N}_{2} \mathrm{O}$ and $50 \% \mathrm{O}_{2}$ was used for maintainance of anesthesia. Dexamethasone iv $0.1 \mathrm{mg} / \mathrm{kg}$ and ondansetron $0.1 \mathrm{mg} / \mathrm{kg}$ iv were given to all patients before the onset of surgery. Fifteen $\mathrm{mg} / \mathrm{kg}(15 \mathrm{mg} / \mathrm{kg})$ paracetamol was administered for postoperative pain management 10 minute before the end of the surgery. After removal of the mouth gag, anesthetic gases were closed at the end of the operation. When the patient's respiratory effort was seen, neostigmine $(0.05 \mathrm{mg} / \mathrm{kg})$ and atropine $0.02 \mathrm{mg} / \mathrm{kg}$ were added to reverse the neuromuscular blockade. After adequate spontaneous breathing was observed with capnograph, the intubation tube was removed. The patients regained the cough 
and gag reflex. Then all patients were transferred to the post anesthesia care unit (PACU) on their lateral side. The surgical time (from the insertion of mouth gag to the removal of mouth gag), anesthesia time (from the mask application to the extubation), eye opening time (from the extubation to the eye opening) and extubation time ( from the discontinuation of anesthetic agents to the extubation) were all recorded. In addition age, gender, body mass index, MAS scale, m-ypas scale scores were recorded too. In PACU a trained anesthesia member evaluated the emergence delirium with PAED scale (pediatric emergence delirium scale) and pain with FLACC and OPS scale 5 min after arrival of the PACU, 15 min after arrival of the PACU and 30 min after arrival of the PACU. The indicator of ED is the score of $\geq 10$ with PAED scale. The components of PAED are indicators of both delirium and pain. ${ }^{9}$ The components of ED1 (eye contact, awareness of the surroundings and purposeful action) reflects better delirium behaviours, the components of ED2 (consolability and restlessness) reflects better pain behaviours. ${ }^{9}$ The score of FLACC 4 and over 4 and the score of OPS over 5 were the indicators of pain. When the patients presented with pain and ED, $0.5 \mathrm{mcg} /$ $\mathrm{kg}$ fentanyl was administered as rescue treatment and repeated at each time period. Any adverse effects in postoperative period was recorded (such as nause, vomiting, laryngospasm, bronchospasm).

Sample size calculation: According to the preliminary data of this study (the estimated insidence of ED was $56 \%$ and the insidence of pain was $36 \%$ ) a sample size of 52 patient required to find the difference between pain and ED, with 0.90 power and an alpha level of 0.05 . Taking into dropout rate of $10 \%$, the study population included 61 patient.

Statistical analysis: Data analysis was performed using the SPSS program for Windows version 20.0 statistical package (IBM Corporation, Armonk, NY, USA). Kolmogorow-Smirnow test was performed for analysis of normal distribution to data. The data were presented as mean and standard deviation or median (IQR) according to the normal distribution compatibility analysis result. Categorical and dichotomous data are presented as numbers and percentages.

Spearman Correlation analysis was performed to evaluate the correlation between FLACC and OPS, FLACC and PAED scales, OPS and PAED scales, $m$ -YPAS and PAED scales.

The ability of FLACC and OPS were investigated to detect ED1 (as indicator of agitation) and ED2 (as indicator of pain). The positive case of ED1 was $\geq 6$ and the positive case of ED2 was $\geq 4$. $^{9}$ The sensitivity and specifity of FLACC and OPS were analysed using receiver operating characteristic (ROC) curve methodology. Positive and negative predictive values were also presented.

\section{RESULTS}

Sixty one (61) children were included in this study. Demographic and anesthetic characteristics of the participants were shown in Table 1. The mean scores of FLACC, PAED, OPS and m-YPAS were presented in Table 2. During the 30-minute evaluation, the number of patients who developed emergence delirium in at least one time interval was fifty (50) (Table 3 ). Only the number of children with delirium were $29(47.5 \%)$, only the number of children with pain were $10(16.4 \%)$ and the number of children with both delirium and pain were 25 (40.9\%) (Table 3). The insidence of delirium and the insidence of pain decreased over time during the first thirty minute after arrival of the PACU (Table 3). There was a correlation between PAED and FLACC scale ( $r=0.568, p<0.001$ at $5 \mathrm{~min} ; \mathrm{r}=0.495, \mathrm{p}<0.001$ at $15 \mathrm{~min}, \mathrm{r}=0.449, \mathrm{p}<0.001$ at $30 \mathrm{~min})$. There was a correlation between PAED and OPS scale $(r=$ $0.651, \mathrm{p}<0.001$ at $5 \mathrm{~min} ; \mathrm{r}=0.641, \mathrm{p}<0.001$ at 15 min, $r=0.432, p<0.001$ at $30 \mathrm{~min}$ ). There was a correlation between FLACC and OPS scale $(r=$ $0.627, \mathrm{p}<0.001$ at $5 \mathrm{~min} ; \mathrm{r}=0.500, \mathrm{p}<0.001$ at 15 $\min , \mathrm{r}=0.512, \mathrm{p}<0.001$ at $30 \mathrm{~min}$ ). There was a correlation between PAED and $\mathrm{m}$-YPAS scale $(\mathrm{r}=$ $0.307, \mathrm{p}<0.001$ at $5 \mathrm{~min} ; \mathrm{r}=0.308, \mathrm{p}=0.001$ at 15 $\min , \mathrm{r}=0.383, \mathrm{p}<0.001$ at $30 \mathrm{~min}$ ).

FLACC had a sensitivity of 0.85 and a specifity of 1.00 to identify ED2 (pain indicator component of PAED) at 5th min, had a sensitivity of 0.63 and a specifity of 1.00 at 15 th $\mathrm{min}$, OPS had a sensitivity of 0.66 and a specifity of 0.86 to identify ED2 (pain indicator component of PAED) at 5th min, had a sensitivity of 0.63 and a specifity of 0.65 at 15 th $\min$,

The area under the curve value (AUC) for OPS was high (AUC $=0.734, \mathrm{P}=0.005)$, indicating to identify ED1 (components of delirium indicators) at 15th min (Figure 1). The area under the curve value (AUC) for FLACC was high $(\mathrm{AUC}=0.914, \mathrm{P}=$ 0.02 ), indicating to identify ED2 (components of pain indicators) at 5th min (Figure 2). The area under the curve value (AUC) for FLACC was high (AUC $=0.865, \mathrm{P}<0.001)$, indicating to identify ED2 (components of pain indicators) at 15th min 
(Figure 2).

\section{DISCUSSION AND CONCLUSION}

Negative behavioral changes are frequently observed in children in the postoperative period in ear-nosethroat surgery. Emergence delirium and pain are the often seen post operative early period complications after tonsillectomy with or without adenoidectomy. ${ }^{10}$ For emergence delirium and pain, often diagnostic scales are used and necessary treatment is given. ${ }^{11}$ PAED is the most common standardized scale for diagnosing pediatric emergence delirium. ${ }^{4}$ FLACC and OPS are the most common scales for diagnosing pain. ${ }^{7,8}$ Although FLACC and OPS, which are pain scales, are used to differentiate pain from ED, it is intertwined with delirium in terms of its components (restlessness, discomfort). ${ }^{9}$ So, ED and pain must be separated from each other in order to provide appropriate treatment. It was found that the PAED scale was not specific for distinguishing delirium in the child's restlessness and discomfort (ED2). ${ }^{12}$ In addition, it was observed that the child did not have eye contact with the caregiver, had involuntary movements, and was unconscious with what was going on around her/his as more specific items in terms of delirium (ED1). ${ }^{12}$ When looking at the components of the standardized PAED scale, which is the most frequently used to describe ED, it was observed that it can be separated to define both pain and delirium. ${ }^{12}$ In this previous study, PAED scale components were separated as ED1 and ED2 using the FLACC scale. $^{12}$

In the present study we used both FLACC and OPS scales. We found that FLACC scale can better used for distinguishing the pain (ED2) and delirium (ED1) components at 5th and 15th min after arrival of the PACU, in pediatric patients undergoing tonsillectomy with or without adenoidectomy. Also, the area under the curve for the ED1 component was high for the OPS scale, which shows us that the OPS scale can also be an indicator for the delirium component of ED too. In other words, it will be more difficult to differentiate ED and pain when using the OPS scale.

The frequency of emergence delirium is relatively higher in children undergoing ear, nose and throat surgery compared to other surgeries. ${ }^{13}$ At the same time, pain is also common in children who undergo adenoidectomy and pain and delirium are often together. ${ }^{14}$ In the present study, the incidence of children with delirium $(47.5 \%)$ was nearly same as the incidence of children with both delirium and pain
$(40.9 \%)$ too. It has also been observed that delirium sometimes decreases spontaneously over time. And also both ED and postoperative pain decrease with appropriate treatment over time like the other studies. $^{15}$

The moderate to high correlation between pain and delirium (PAED) shows us how pain and pediatric emergence delirium intertwined in this study similar to other investigations. ${ }^{16} \mathrm{We}$ evaluated pain with both pain scales (FLACC and OPS) and we saw there was significant correlation between the pain scales and ED scale.

A significant relationship between preoperative anxiety and post-operative delirium has also been demonstrated in studies. ${ }^{16,17}$ Although it is low, in this study, a significant relation was found between anxiety in the preoperative period and pediatric emergence delirium in the post-operative period.

One of the limitation of this study is that delirium and pain measured in the 5th, 15th and 30th minutes in the postoperative period. The evaluations could be measured more frequently. So in this way, there may not be missed values in some ranges. The another is obvious that, even at the beginning, in the preoperative period, all children may not be able to make eye contact, show awareness about the environment or maintain calm behavior (all these behaviors are evaluated and rated by PAED). Therefore, PAED scales can be evaluated in the preoperative period.

In future studies, we think that the number of patients can be increased and so a wider pediatric population can be differentiated and pain and pediatric emergence delirium can be differentiated in different pediatric surgeries using different pain scales.

In conclusion, both of the FLACC and OPS pain scales had high sensitivity and specifity for pain measurement. FLACC can be used better than OPS for differentiating the postoperative pain and pediatric emergence delirium.

Ethics Committee Approval: The approval was received from Ethics Committe of Kirıkkale University (Date: 06.02.2020, decision no: 2020/09).

Conflict of Interest: No conflict of interest was declared by the authors.

Author Contributions: Concept - KP; Supervision KP, SAP; Materials - KP; Data Collection and/or Processing - KP; Analysis and/ or Interpretation KP,SAP; Writing -KP;SAP.

Peer-review: Externally peer-reviewed.

\section{REFERENCES}


1. Holly MacDonell. Emergence Delirium: Causation, Correlation and Improvements Needed. EC Pulmonology and Respiratory Medicine. 2019;8:623-629.

2. Wong DDL, Bailey CR. Emergence delirium in children. Anaesthesia. 2015;70(4):383-387.

3. Bajwa S, Fanzca DC, Drcog AMC. A comparison of emergence delirium scales following general anaesthesia in children. Paediatr Anaesth. 2010;20:704-711.

4. Sikich N and Lerman J. Development and psychometric evaluation of the pediatric anaesthesia emergence delirium scale. Anesthesiology. 2004;100:1038-1045.

5. Pancekauskaitė G, Jankauskaitė L. Paediatric Pain Medicine: Pain Differences, Recognition and Coping Acute Procedural Pain in Paediatric Emergency Room. Medicina (Kaunas). 2018;54 (6):94. doi:10.3390/medicina54060094

6. Buttner W, Finke W, Büttner W, Finke W. Analysis of Behavioural and Physiological Parameters for the Assessment of Postoperative Analgesic Demand in Newborns, Infants and Young Children: A Comprehensive Report on Seven Consecutive Studies. Paediatr Anaesth. 2000;10:303318. doi: 10.1046/j.1460-9592.2000.00530.x

7. Merkel SI, Voepel-Lewis T, Shayevitz JR, Malviya S. The FLACC: A behavioral scale for scoring postoperative pain in young children. Pediatr Nurs. 1997;23:293-297.

8. Broadman LM, Rice LJ, Hannallah RS. Testing the validity of an objective pain scale for infants and children. Anesthesiology. 1988;69:A770.

9. Somaini M, Engelhardt T, Fumagalli R, et al. Emergence delirium or pain after anaesthesiahow to distinguish between the two in young children: a retrospective analysis of observational studies. Br J Anaesth. 2016;116:377-383.

10. Tuomilehto H, Kokki H, Ahonen R, Nuutinen J. Postoperative Behavioral Changes in Children After Adenoidectomy. Arch Otolaryngol Head Neck Surg. 2002;128(10):1159-1164. doi:10.1001/archotol.128.10.1159

11. Lee CA. Paediatric emergence delirium: an approach to diagnosis and management in the postanaesthesia care unit. Perioper Crit Intensive Care Nurs. 2017;3:140. doi:10.4172/24719870.10000140

12. Somaini M, Sahillioğlu E, Marzorati C, Lovisari $\mathrm{F}$, Engelhardt T, Ingelmo PM. Emergence delirium, pain or both? A challenge for clini- cians. Paediatr Anaesth. 2015;25(5):524-529. doi:10.1111/pan.12580

13. Aldakhil SK, Salam M, Albelali AA, Alkanhal RM, Alnemer MJ, Alatassi A. The prevalence of emergence delirium and its associated factors among children at a postoperative unit: A retrospective cohort at a Middle Eastern hospital. Saudi J Anaesth. 2020;14(2):169-176. doi:10.4103/sja.SJA_573_19

14. Mehrotra S. Postoperative anaesthetic concerns in children: Postoperative pain, emergence delirium and postoperative nausea and vomiting. Indian J Anaesth. 2019;63(9):763-770. doi:10.4103/ija.IJA_391_19

15. Nair S, Wolf A. Emergence delirium after paediatric anaesthesia: new strategies in avoidance and treatment. BJA Education. 2018;18(1):30-33.

16. Mohkamkar M, Farhoudi F, Alam-Sahebpour A, Mousavi SA, Khani S, Shahmohammadi S. Postanesthetic Emergence Agitation in Pediatric Patients under General Anesthesia. Iran J Pediatr. 2014;24(2):184-190.

17. Kain ZN, Caldwell-Andrews AA, Maranets I. Preoperative anxiety and emergence delirium and postoperative maladaptive behaviors. Anesthesia \& Analgesia. 2005;99(6):1648-1654. 
Table 1. Demographic and anesthetic characteristics of patients.

\begin{tabular}{|l|l|}
\hline $\mathrm{N}=61$ & Mean \pm Standart Deviation \\
\hline Age (year) & $5.39 \pm 2.53$ \\
\hline Sex F/M, N (\%) & $27 / 34(\% 46.8 / \% 53.2)$ \\
\hline Weight (kilogram) & $21.30 \pm 6.49$ \\
\hline Anesthesia duration (min) & $40.34 \pm 8.70$ \\
\hline Surgery duration (min) & $34.43 \pm 5.79$ \\
\hline Eye opening time (min) & $6.30 \pm 1.36$ \\
\hline Extubation time (min) & $4.26 \pm 1.88$ \\
\hline Complication, N (\%) & \\
Nausea & $4(\% 3.7)$ \\
Nausea and vomiting & $6(\% 5.5)$ \\
\hline
\end{tabular}

$\mathrm{N}$, number; F, female; $\mathrm{M}$, male 
Table 2. Scores of delirium, pain and anxiety of children.

\begin{tabular}{|l|l|}
\hline & Mean \pm Standart Deviation \\
\hline FLACC 5 min & $7.30 \pm 1.42$ \\
\hline FLACC 15 min & $3.39 \pm 1.75$ \\
\hline FLACC 30 min & $1.91 \pm 0.79$ \\
\hline PAED 5 min & $13.91 \pm 3.59$ \\
\hline PAED 15 min & $8.08 \pm 2.17$ \\
\hline PAED 30 min & $5.52 \pm 2.71$ \\
\hline OPS 5 min & $5.78 \pm 1.24$ \\
\hline OPS 15 min & $2.73 \pm 1.42$ \\
\hline OPS 30 min & $1.86 \pm 1.05$ \\
\hline m-YPAS (preoperative) & $51.94 \pm 1.57$ \\
\hline
\end{tabular}

"Face, Legs, Activity, Cry, Consolability" (FLACC) is a pain scale; "Pediatric Anesthesia Emergence Delirium" (PAED)is a delirium scale; "Objective Pain Scale" (OPS) is a pain scale; "Modified Yale Preoperative Anxiety Scale" (m-YPAS) is an anxiety scale; min, minute 
Table 3. The insidence of emergence delirium, pain, both emergence delirium and pain in children.

\begin{tabular}{|l|l|l|l|}
\hline $\begin{array}{l}\text { Association between ED } \\
\text { and pain }\end{array}$ & $\begin{array}{l}5 \text { th min } \\
\mathrm{N}(\%)\end{array}$ & $\begin{array}{l}15 \text { th min } \\
\mathrm{N}(\%)\end{array}$ & $\begin{array}{l}30 \text { th min } \\
\mathrm{N}(\%)\end{array}$ \\
\hline FLACC $\geq 4$ & $25(41 \%)$ & $10(16.4 \%)$ & 0 \\
\hline $\mathrm{PAED} \geq 10$ & $34(55.7 \%)$ & $12(19.7 \%)$ & $4(6.6 \%)$ \\
\hline $\mathrm{OPS} \geq 5$ & $24(39.3 \%)$ & $5(8.2 \%)$ & 0 \\
\hline $\begin{array}{l}\text { PAED } \geq 10 \\
\text { FLACC } \geq 4\end{array}$ & $20(32.8 \%)$ & $5(8.2 \%)$ & 0 \\
\hline $\begin{array}{l}\text { PAED } \geq 10 \\
\text { OPS } \geq 5\end{array}$ & $17(27.9 \%)$ & $4(6.6 \%)$ & 0 \\
\hline $\begin{array}{l}\text { PAED } \geq 10 \\
\text { FLACC }<4\end{array}$ & $14(23 \%)$ & $7(11.5 \%)$ & $4(6.6 \%)$ \\
\hline $\begin{array}{l}\text { PAED } \geq 10 \\
\text { OPS }<5\end{array}$ & $17(27.9 \%)$ & $8(13.1 \%)$ & $4(6.6 \%)$ \\
\hline $\begin{array}{l}\text { PAED }<10 \\
\text { FLACC } \geq 4\end{array}$ & $5(8.2 \%)$ & $5(8.2 \%)$ & 0 \\
\hline $\begin{array}{l}\text { PAED }<10 \\
\text { OPS } \geq 5\end{array}$ & $7(11.5 \%)$ & $1(1.6 \%)$ & 0 \\
\hline
\end{tabular}

$\mathrm{ED}$, emergence delirium; $\mathrm{N}$, number; 5 th min, 5 minute after arrival of the recovery room; 15 th min, 15 minute after arrival of the recovery room; 30th min, 30 minute after arrival of the recovery room; "Face, Legs, Activity, Cry, Consolability" (FLACC) is a pain scale; "Pediatric Anesthesia Emergence Delirium" (PAED)is a delirium scale; "Objective Pain Scale" (OPS) is a pain scale; "Modified Yale Preoperative Anxiety Scale" (m-YPAS) is an anxiety scale; min, minute. 

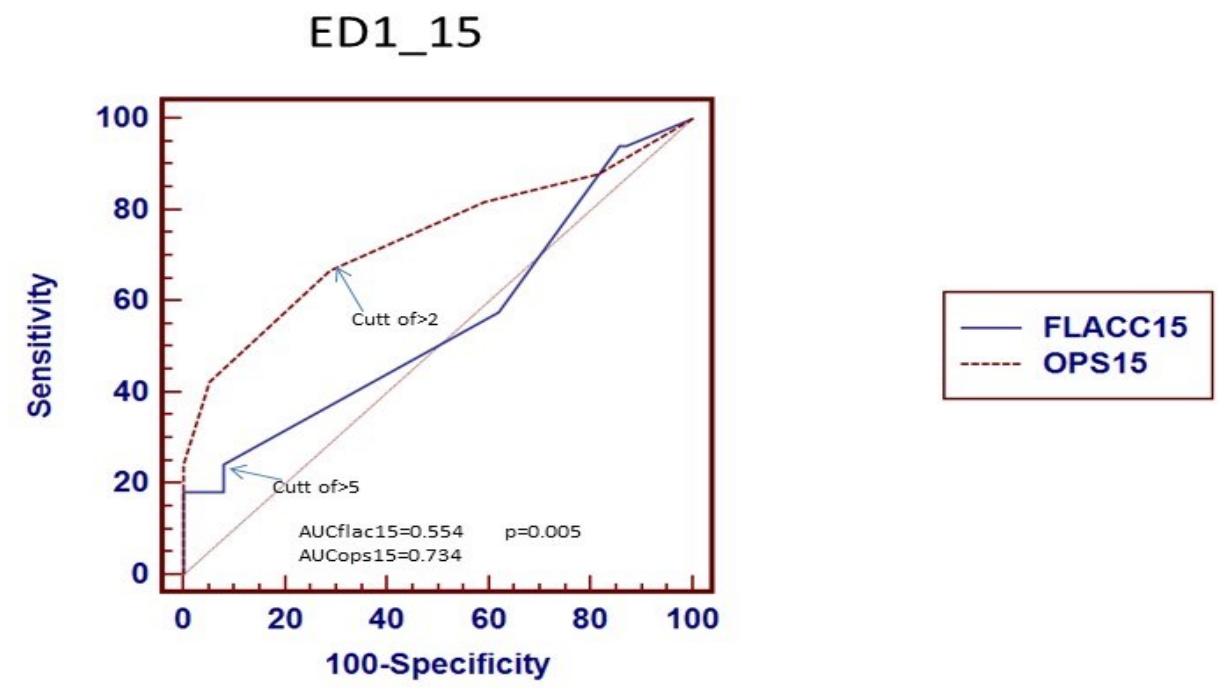

Figure 1. Receiver operating characteristics (ROC) curves of FLACC and OPS on detecting ED1 at 15 th minute.

ED, emergence delirium; FLACC15, "Face, legs, Activity, Cry, Consolability" scale at 15th min after arrival of the recovery room; OPS15, objective pain scale at 15 th min after arrival of the recovery room; AUC, area under the curve 
ED2_5

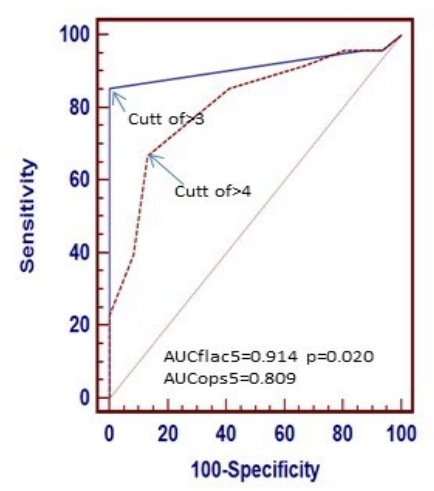

ED2_15

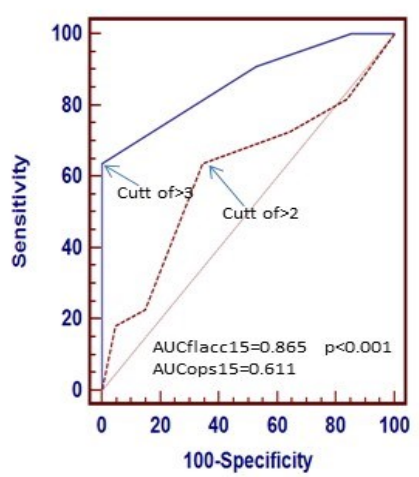

- FLACC15

- FLACC5 OPS5

Figure 2. Receiver operating characteristics (ROC) curves of FLACC and OPS on detecting ED2 at 5th min and 15th minute.

ED, emergence delirium; FLACC5, "Face, legs, Activity, Cry, Consolability" scale at 5th min after arrival of the recovery room; OPS5, objective pain scale at 5th min after arrival of the recovery room; FLACC15, "Face, legs, Activity, Cry, Consolability" scale at 15 th min after arrival of the recovery room; OPS15, objective pain scale at 15 th min after arrival of the recovery room; AUC, area under the curve 